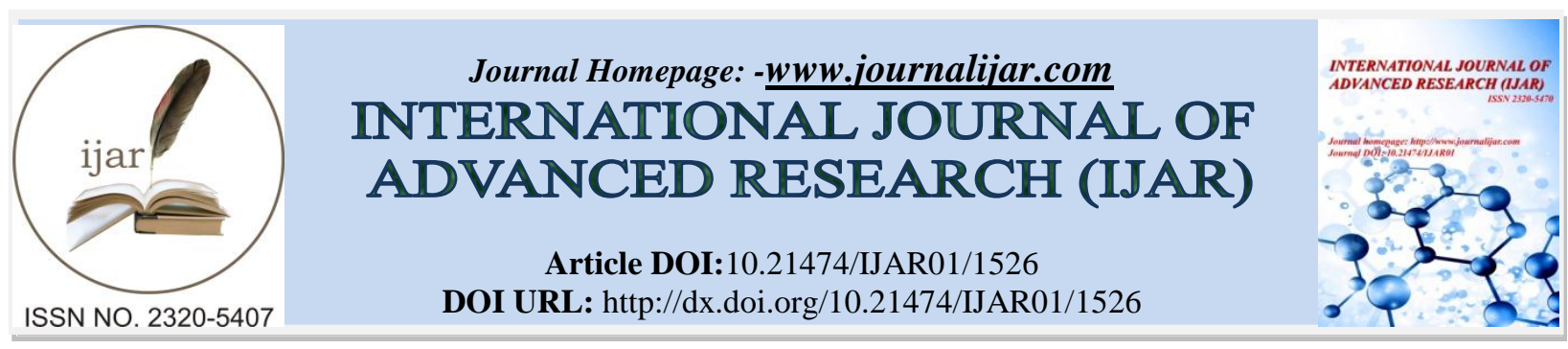

RESEARCH ARTICLE

\title{
CRITICAL READING STRATEGIES, READING COMPREHENSION AND WRITING PERFORMANCE OF ESL COLLEGE STUDENTS: A CORRELATIONAL STUDY.
}

\section{Carine Iries M. Suacillo ${ }^{1}$, Song Eun $\mathrm{Um}^{2}$, Joeseph M. Velasquez ${ }^{3}$, Hannah Nicole R. Villaflores ${ }^{4}$, Maria B.} Cequeña ${ }^{5}$.

1. ESL Teacher, Bachelor in Secondary Education, major in English,University of Santo Tomas, Philippines.

2. High School Teacher, Bachelor in Secondary Education, major in English, University of Santo Tomas, Philippi nes.

3. High School Teacher, Bachelor in Secondary Education, major in English, University of Santo, Philippines, To mas.

4. Bachelor in Secondary Education, major in English, University of Santo Tomas, Philippines.

5. Asst. Professor, Ph.D. Education, Reading Education, University of Santo Tomas, Philippines.

\section{Manuscript Info}

Manuscript History

Received: 15 July 2016

Final Accepted: 19 August 2016

Published: September 2016

Key words:-

critical reading strategies, reading

comprehension, analytical writing

\section{Abstract}

A genuine and substantial acquisition of knowledge requires more than the regular reading ability but rather that of critical reading which translates to increased critical thinking, deeper reader comprehension, and more effective analytical writing (Kurland, 1998). Improving critical reading skills requires the application of critical reading strategies (Critical Reading Strategies, 2009). This study was conducted in response to a serious dilemma that exists in the Philippine educational setting wherein a significant number of students fail to exercise critical reading; as such, they merely gather details or ideas, and often accept the information in the text at face value without applying critical thinking (Imam, 2013). The paper aims to establish the correlation among critical reading strategies, reading comprehension, and writing performance. This quantitative research study was conducted among the third-year college students from a reputable university in the country. The students were given a standardized reading comprehension test, an analytical writing task, and a researcher-made survey questionnaire. The results were analyzed and interpreted using mean and Pearson $r$ in determining the specific critical reading strategies that these students utilized and in establishing the relationship between and among the variables under study. Results show that most respondents utilized two critical reading strategies such as reflecting on the challenges to beliefs and values and contextualizing. There is a moderate positive correlation between critical reading strategies and reading comprehension, between critical reading strategies and analytical writing performance, and between reading comprehension and writing performance. Henceforth, findings of the study will help struggling Filipino readers, particularly those ESL college students become better readers, writers, and 
academic performers through the utilization of critical reading strategies.

Copy Right, IJAR, 2016,. All rights reserved.

\section{Introduction:-}

Reading plays a significant role in students' academic life. Pretorius (2010) found a strong correlation between students' reading proficiency and their academic success by explaining that more reading leads to higher grades. However, in the Philippines, reading is often combined with other subjects which means lesser time for students to develop their comprehension skills (Philippine Star, 2010). This results inpoor reading comprehension skills.Thus, students'performance inother subjects also gets affected.Quijano (2007) describes"reading problems the main culprit for the poor performance of some students in the National Achievement Test(NAT)"(para.4). In this paper, we explore the possibility of addressing this problemthroughgood reading practices (Duke \& Pearson, 2002), particularly the use of critical reading strategies (Salisbury University, 2009; Harvard, 2015). Several scholars have proven the facilitative effect of critical reading strategies on reading comprehension which relates to improved subject area performance (Hinkelmann, 1956; Sochor, 1958; Linvile,1970; Dawe,1983 ; Krantez, 1957 cited in Kopiyo, 1982; Muhandiki, 1984; Duke \& Pearson (2002); Khabiri\&Pakzad, 2011;Sandy Ming -San Chang, 2013; Kadir et.al., 2014)especially on reading and writing. Carson and his colleagues (1990) and Yu (2015) state that a person who excels in reading will more likely excel in writing. Thus, this research aims to provide instructional directionson how educators can helpstruggling readers to be better readers and writers, and to lead them to be better academic performers through theutilization of critical reading strategies.

\section{Literature Review:-}

Reading has been the focus of most research studies for the past decades. Reading as defined by Oxford Dictionary (2015), is "to look at and comprehend the meaning of (written or printed matter) by mentally interpreting the characters or symbols of which it is composed."According to Козак (2011), reading is a complex activity that involves both perception and thought that allows us to interpret a certain message to gain information from a text. Reading, therefore, is an active activity that requires skill and cognitive ability used to understand messages. Critical reading, however, is a "more active way of reading" (Duncan, 2014, para.1). Furthermore, critical reading is much more complex than reading in the sense that critical reading is not just a process of interpreting the message of the text, but it also analyzes and evaluates the said text. Leicester University (2009) describes critical reading as: examining the evidence or arguments presented; checking out any influences on the evidence or arguments; checking out the limitations of study design or focus; examining the interpretations made; and deciding to what extent the reader is prepared to accept the authors' arguments, opinions, or conclusions.

In order to develop critical reading, it is essential to teach critical reading strategies. Salisbury University's (2009) presents seven strategies namely previewing, contextualizing, questioning, reflecting on challenges to your beliefs and values, outlining and summarizing, evaluating, and comparing and contrasting.

Previewing is focused on learning about the text before reading it thoroughly, but previewing criticallydoes not only include looking at the style, the title and subtitle of the text, but also getting an overview of its content and organization as well as identifying its rhetorical situation (skimming).Several studies (Echevarriaet al., 2008; Sousa, 2011; McCormick, 1989; Dole, Valencia, Greer, \& Wardrop,1991; McCormick, 1898) claimed that previewing helps learners improve comprehension by tapping on prior knowledge.

Another critical reading strategy is contextualizing. Contextualizing is "placing a text in its historical, biographical, and cultural contexts" (Salisbury University, 2009,para.1). In this strategy, the reader understands that the writing was written in the past so the reader contextualizes and recognizes the differences of the contemporary values and attitudes and those represented in the text (Graves,1998). In contextualizing a reading material, the reader must consider whether its historical, cultural, material, or intellectual circumstances change, complicate, explain, deepen or otherwise influence his/her view of the writing (Harvard University, 2015). Contextualizing a text requires the reader to identify the text's contextand interprethow its context differs from that of his/her own.This can be achieved by identifying the language or ideas that appear foreign or out of date; involving one's knowledge of the time and place in which the work was written; and finally, evaluating the effect these differences have on one's understanding and judgment of the text (Axelrod \& Cooper, 1998). 
Questioning as a critical reading strategy, on the other hand, encourages readers to write down questions anytime during reading (Salisbury University, 2009). Salisbury University posited that “... in difficult academic readings, you will understand the material better and remember it longer if you write a question for every paragraph or brief section" (para.3). Lastly, Salisbury University (2009) advised that each question should be focused on the main idea and should be answered with the readers' own words and not taken from the paragraphs.Research shows that posing questions and discussing stories before and after reading stories to children enhance comprehension (Bissett, 1970; Crowell \& Au, 1979; Huck, 1976; Lamme 1981 cited in Morrow, 1984). Studies suggest that it is necessary to include all levels of traditional questioning for optimal comprehension development (Guszak, 1967; Hansen, 1981; Lanier \& Davis, 1972; Schwartz \&Sheff, 1975; Wolf, Huck, \& King, 1967 cited in Morrow, 1984). Several researchers propose that question generation is essential in cognitive process that operates at deep conceptual levels like reading comprehension (Collins, Brown, \& Larkin, 1980; Graesser, Person, \& Huber, 1992; Graesser\& Clark, 1985; Hilton, 1990; Kintsch, 1998 cited in Craig et al, 2000).

Reflecting on challenges to one's beliefs and values, as a critical strategy, is applied in reading a text as the reader marks the paragraphs that somehow challenge his attitude, belief, and status. In addition, readers can also note down the reason why a certain text was created and then look at the pattern of concepts that somehow challenges his/her beliefs (Salisbury University, 2009).A critical reader's reflection on his beliefs and values crucially involves examining the basis for his/her own personal responses to the material read (Halpern, 2003). Accordingly, sometimes the readers' beliefs about an issue are difficult to express because they are so ingrained. In order to discover these beliefs, it is important to explore how a text challenges the reader, as to whether the texts disturbed, threatened, ashamed, or inspired him/her. Many readers may have a strong reaction to some of the essays read (Axelrod \& Cooper, 1999).

Outlining and summarizing as described by Salisbury University (2009) is identifying the main ideas and restating them in one's own words.

The key to both outlining and summarizing is being able to distinguish between the main ideas and the supporting ideas and examples. The main ideas form the backbone, the strand that holds the various parts and pieces of the text together. Outlining the main ideas helps you to discover this structure. When you make an outline, don't use the text's exact words. (para.5).

Anderson-Medius (1990) argue that outlining, as a graphic organizer, is a high level skill since outlining requires readers to analyze and see the relationship between information in order to connect them appropriately. Biano and McCormick (1989) further detail that outlining has five functions: (1) allows learners to focus on important ideas); (2) improves familiarity with the structure of the text; (3) promotes better retention; (4) produces alternative materials to supplemental material; (5) encourages participation in learning.Slater, Graves, and Piche(1985)argue that the use of structural organizers using the outline grid supports comprehension and learning.Ivino(1989) supports the claim that outlining shows significance in helping academically underprepared $\mathrm{L}_{1}$ college readers to achieve better comprehension. A study conducted by Doctorow, Wittrock, and Marks in 1978 shows that 6th graders who used paraphrasing performed significantly better in multiple choice test and delayed cloze recall test whereas a similar finding in a study conducted by Dansereau and his colleagues (1974) shows that college students who paraphrased demonstrated a higher group mean on essay exams.Furthermore, Corder-Ponce (2000) argues that summarization is possibly the most significant and encompassing of all reading strategies for effective studying and better comprehension.

Next is evaluating. Evaluation of the text read means that the reader analyzes how the text evidence portrays the subject matter (Bisset, 2014). A critical reader is required to make a careful evaluation of the degree of importance and acceptance he is to confer on the text read, taking into account the author's topic presentation and the validity of his arguments.As opposed to ordinary reading where the reader only accepts the information presented in the text, critical reading serves a different purpose, where the reader does not just accept the information, but judges and evaluates the author's argument of the text (Salisbury University, 2009).Furthermore, evaluation assumes the readers' careful examination of the decisions or choices the author made in framing the presentation ofcontent, language, and structure of the text. Readers examine each of the three areas of choice, and consider their effect on text meaning (Kurland, 1998). Another area of evaluation is the logic of the author's argument.The two parts of an argument are claim and support. Claim is what the writer wants the reader to accept. Thus, the claim refers to the writer's idea, opinion, or point of view.Support refers to the reasons and evidence that serve as the basis for the 
claim. In testing the logic of the author's argument, the reader must evaluate the arguments in terms of appropriateness, believability, and consistency throughout the entire course of the reading. Testing for appropriateness requires analyzing the text according to logical fallacies for instance false analogy, non sequitur, post hoc ergo propter hoc. Next, testing for believability requires applying other fallacies that relate to reasoning, such as begging the question, generalizations and failing to accept the burden of proof. Finally, testing for consistency requires checking to make sure there are no contradictory statements (Axelrod \& Cooper, 1998).

Finally,comparing and contrasting isdescribed as exploring likenesses and differences between texts to understand them better. The reader differentiates and connects various texts to the previously read text in order to analyze their similarities and differences.Silver (2015) posits that comparing and contrasting consists of five distinct goalsnamely: (1.) strengthen memories by focusing on analyzing pairs of ideas, thus strengthens the reader's ability to remember key contents; (2.) develop higher-order thinking skills; (3.) increase comprehension by highlighting the significant details, making abstract ideas concrete, and reduction of confusion between related concepts; (4.) enhance writing in content areas through a simple structure that organizes information and develop ideas with greater clarity and accuracy; (5.) develop habits of mind. Costa and Kallick $(2008,2009)$ cited in Silver state that enhancing the habits of mind such as thinking about thinking (metacognition), thinking flexibly, applying prior knowledge to new situations, striving for accuracy, and thinking and communicating with clarity and precision will provide students with tools that can help orchestrate their academic success. Furthermore, Allen (2004) describes the process of comparing and contrasting as helpful in clarifying concepts and making information memorable by asking the readers to think deeply about the text in order to determine the similarities and differences.

\section{Critical Reading Strategies and Reading Comprehension:-}

Duke and Pearson (2002) posit that the readers' application of critical strategies enhances reading comprehension. In 2007, Jasim'sstudyabout critical reading strategies shows that critical reading strategies should be an integral part of advanced reading courses for they have a positive impact on students' capability to differentiate facts from opinions, make inferences, recognize bias and prejudice, and identify various types of propaganda. In 2011, Khabiri and Pakzadhave also found that the application of critical reading strategies help students improve their vocabulary and make its retention easier, thus helping them become more independent and successful readers.Furthermore, Kadir and his colleagues (2014) posit that the students become critical thinkers by learning first the critical reading skills wherein they were asked to comprehend the text by analyzing, synthesizing, and evaluating. Similarly, Nasrollahi et al. (2015) posit that theuse of critical reading strategies orchestrates the development of critical reading, critical thinking, and higher order thinking ability respectively.Furthermore, $\mathrm{Yu}(2015)$ reveals thatcritical reading strategies lead to better comprehension in college English reading, and the most frequently used reading strategies in university classroom teaching are: (1) pre-reading, (2) reading in context, (3) questioning and answering, (4) reflecting after reading, and (5) outlining and summarizing.

\section{CriticalReading and Critical Writing:-}

Reading and writing connection can be established by analyzing the two processes and how they are being employed. According to Tompkins (1999), readingandwriting are similar. The first step in both processes involves using and activating background knowledge and being able to set a purpose in doing whichever process is supposed to be used. As a result, a student becomes literate through both reading and writing. Furthermore, readers and writers use the same strategies; this means that what is applicable in one process can also be applicable to the other. Reading and writing skills can both be developed by using strategies like questioning and paraphrasing, but one strategy does not suit all texts. Flemming (2009) suggests that readers should try different approaches especially if the first approach does not work. He adds that there should be flexibility when it comes to the use of strategies in reading and writing. This way, the text can be more easily understood and writing about it will be easier.

Throughout the various stages of our studies in school, we have all been made to read various academic textsstories, essays, and almost everything else in written literature; and afterwards, we were then made to write a number of responses, reflections, reactions, and/or analyses to quite a number of these printed texts. It can therefore be assumed that reading and writing essentially go hand-and-hand with each other. With this, it is natural to believe that if one reads, one ought to be able to understand or comprehend what he reads (Snow, 2002), and having this considerable understanding or comprehension of a text read would then enable the said reader to write on or about it if required to (Kurland, 1998).According to Kurland (1998), "all writers rely on their skills as readers" (para.4). Therefore,"reading is primary; one can write only as well as one reads"(para.2). Furthermore, he states that "to write better, you must learn to read better"(para. 5).This fact highlights the significant role that critical reading plays in 
order for the reader to practice critical thinking that will enable him to do analytical writing. Thus, critical thinking depends significantly on critical reading wherein one can only objectively and rationally critique a text if he substantially and truly understands the contents and thoughts of that text (Kurland, 1998). According to the University of Leicester (n.d.), "critical reading is an important precursor to critical writing;" (para. 1) likewise, "critical writing depends on critical reading" (Knott, 2002, para. 1).Hence, achieving proficiency in critical reading requires the use of critical reading strategies (Axelrod \& Cooper, 1999).Among critical reading strategies, focus can be made on three essential techniques that present substantial correlation to both enhanced reading comprehension and improved analytic writing performance, namely: 1) evaluation of the text read; 2) contextualizing the information from the text; and 3) reflecting on the reader's values and beliefs in relation to the texts read.

Moreover, Axelrod and Cooper (1999) state that the development of advanced critical writing skills is a direct result of enhanced critical reading which can be achieved through the application of selected critical reading strategies. The study also purports that in order to achieve an improved critical reading ability, it would require the application of some critical reading strategies (Salisbury University, 2009; Harvard, 2015).

Numerous researches on the impact of critical reading strategies on thinking ability, vocabulary, and comprehension skills have been done. However, previous studies do not take into account the correlation of critical reading strategies with reading comprehension and writing performance, and which specific strategies would actually affect students' reading comprehension and writing performance. Hence, this study aimed to fill in this research gap by investigating the correlation among critical reading strategies, reading comprehension, and writing performance.It involves responses from third-year pre-service education students in a prestigious university enrolled during the school year 2015-2016. This research looked into the critical reading strategies that the respondents utilized, and if these strategies had significant effect on their performance in the reading comprehension and analytical writing test.

This study aims to answer the following questions:

1. What critical reading strategies are frequently used by third year college students?

2. Is there a significant relationship between the third year collegestudents' use of criticalreading strategies and their reading comprehension?

3. Is there a significant relationship between the third year collegestudents' critical reading strategies andtheir analytical writing performance?

4. Is there a significant relationship between the third year collegestudents'reading comprehension and their analytical writing performance?

\section{Research Design:-}

This correlational study used quantitative approach to find out the impact of critical reading strategies in improving reading comprehension and writing performance.

\section{Participants:-}

The participants of this study comprised 45 random third year education students from a catholic university. Their ages ranged from 18-20 years old. Participants were from the Bachelor in Secondary Education, major in Math, English, Filipino, Religious Education, and Science, and Bachelor in Elementary Education, major in Special Education, Food Technology, Nutrition and Dietetics, and Library Science program. Pre-service education students were purposely chosen as the respondents of the study since they would be future educators, it would be beneficial to find out which critical reading strategies they have already acquired and applied and which strategies they should still enhance so that they, too, can develop the same skills among the students who will be entrusted to their care.

\section{Instruments:-}

The following instruments were used in this study:

\section{Critical Reading Strategies Likert Scale:-}

A 61-item Critical Reading Strategies Likert scale was a researcher-made instrument based on Salisbury University and Harvard University's description of critical reading strategies. It is a five-point Likert scale with the following scales 5- always, 4- often, 3 - sometimes, 2- rarely, 1- never.The researcher-made Likert scale survey was pilot tested to 60 random students with the same age range as the participants. The instrument was validated by two (2) language experts, one (1) literature expert, and two (2) statisticians and was subjected to confirmatory factor analysis to ensure its validity and reliability. The result of confirmatory factor analysis shows that most items under 
each construct, with the exception of the construct Previewing, are convergent and share a high proportion of variance in common. The validation process reducedthe original 70-item Likert scale to 61 items having five (5) items removed in previewing, one (1) item in contextualizing, one (1) item in questioning, one (1) item in reflection on the challenges to beliefs and values, and one (1) item in evaluation.

Cronbach's Alpha was used to validate and determine the internal consistency of items in a survey. The Likert Scale surveygenerated a Cronbach's alpha value of 0.85 which indicates that the items are consistent and within the acceptable range.

This instrument was used to compare and contrast the participants' utilization and frequency of different critical reading strategies and to determine the effects of using critical reading strategies on the students' reading performance and writing performance. Likewise, this instrument was also used to find out the different critical reading strategies utilized by third year college students.

\section{Reading Comprehension Test:-}

A 35-item reading comprehension test was taken from Test Prep Review: Free Online Practice Testsunder the category of SAT Practice Test. The permission to use the questions was granted by the author sent via email.The reading comprehension test was timed for 36 minutes and participants were given four (4) options per question based on US SAT Critical Reading Test Area.

\section{Analytical Writing:-}

A reading material was read and analyzed by the participants through an essay. The text analyzed was taken from Custom Essay Writing Service. The students were asked to write an analytical essay critiquing the arguments presented on the text provided. Their works were checked by the researchers using a Letter Grade analytical writing rubric adopted from Maria RostRublee (2005) from the University of Tampa and their ratings were validated by a language expert to determine its suitability in rating students' analytical essays. The scoring rubric contains the following criteria: organization, argumentation, support,content knowledge, originality, level of discourse, vocabulary and grammar.The Letter Grades were given a numerical equivalent: A-5, B-4, C-3, D-2, and F-1.In rating students' analytical essays, analytic rubric was used by giving points to each criterion. The results of analytical writing were used to find out whether the critical reading strategies and the reading comprehension predict the writing performance.

\section{Procedure:-}

The researchers selected 45 students from the College of Education through random sampling. The 45 participants were provided with a confidentiality agreement form to assure them that the researcher would implement the no disclosure policy of any information. Simultaneously, they were asked to answer the 61-item Likert scale survey about their critical reading strategies. The reading comprehension test and the analytical writing test were administered on separate days. The reading comprehension testwas administered at the school library. The writing test compriseda reading text,and a writing prompt. They were asked to analyze the text (essay) and provide their stand based on the text and on their analysis. Their essayswererated by three of theresearchers using a rubric adopted from Rublee (2005). Prior to rating students' analytical essays, they calibrated their scoring by discussing their individual rating for a sample essay considering the criteria and descriptors indicated in the scoring rubric.

In analyzing the data, the researchers used descriptive and inferential statistics. To find out the critical reading strategy frequently used by third year collegiate students, weighted mean was used.To establish the correlation between the strategies used by readers and their reading comprehension, as well as their writing performance and reading comprehension, Pearson $r$ was used.

\section{Results:-}

\section{Critical Reading Strategies Employed by College Education Students}

Table 1 shows the results of the critical reading strategies employed by the respondents. Reflecting on the challenges to beliefs and values topped the list (3.689) followed by contextualizing (3.675) while comparing and contrasting related readings and evaluating obtained similar weighted mean (3.378). 
Table 1:-Critical Reading Strategies Employed by the College Education Students.

\begin{tabular}{|c|c|c|}
\hline CRITICAL READING STRATEGY & WEIGHTED MEAN & RANK \\
\hline Previewing & $3.156^{* *}$ & 6 \\
\hline Contextualizing & 3.675 & 2 \\
\hline Questioning & 3.325 & 5 \\
\hline Reflecting on the challenges to beliefs and values & $3.689 * *$ & 3.5 \\
\hline Outlining and Summarizing & $3.378^{* *}$ & 7 \\
\hline Comparing and Contrasting & 3.111 & 3.5 \\
\hline Evaluating & $3.378^{* *}$ & \\
\hline
\end{tabular}

** rounded off to the nearest thousandths

Results of the study reveal a common trait among teenagers that they do not believe easily on what they read but they reflect on their own beliefs and values and compare them with those that they have read from texts. The second critical reading strategy frequently used by the respondents is contextualizing, which means that when they read a text, they consider its background - when and where it was written - to make sense of it. The practice of digging deeper into the text background and reflecting on the challenges to beliefs and values were part of college students' training in almost all courses in the university. This explains the respondents' frequent use of these critical reading strategies. Other critical reading strategies which the respondents were trained to use in learning tasks in a majority of courses include comparing and contrasting related readings and evaluating (ranked 3.5) in this study.

The scores of the reading test accumulated an average of 20.13 out of 35 items as shown in Table 2 . The lowest score is 9 while the highest is 32. The results of the writing test accumulated an average of 3.59. The lowest score is 2.17 while the highest is 4.5 . Considering the means in both tests, the students performed better in analytical writing than in reading test. The reason, perhaps, for this result is that it is easier for students to write their analysis of the essay rather than take the reading test which deals on diverse topics.

Table 2:- Reading Comprehension Test Scores and Analytical Writing Test Scores of the Respondents

\begin{tabular}{|c|c|}
\hline Skills & Mean \\
\hline Reading Comprehension & 20.13 \\
\hline Writing Test & 3.59 \\
\hline
\end{tabular}

Correlation between critical reading strategies and reading comprehension:

Table 3shows the correlation between critical reading strategies and reading comprehension. Results reveal that there is a positive moderate correlation between critical reading strategies and reading comprehension. This implies that the more frequent the students use critical reading strategies, the higher is their reading comprehension.

Table 3:-Correlation between critical reading strategies and reading comprehension of college students.

\begin{tabular}{|c|c|c|c|c|}
\hline STRATEGY & PEARSON $\boldsymbol{R}$ & INTERPRETATION & $\begin{array}{c}\text { SIGNIFICANCE } \\
\text { F }\end{array}$ & INTERPRETATION \\
\hline Previewing & $.133^{* *}$ & Weak $(+)$ & $.385^{* *}$ & NON-SIGNIFICANT \\
\hline Contextualizing & $.422^{* *}$ & Moderate $(+)$ & $.004^{* *}$ & SIGNIFICANT \\
\hline $\begin{array}{c}\text { Questioning } \\
\text { Reflecting on the } \\
\text { challenges to beliefs } \\
\text { and values }\end{array}$ & .177 & Weak (+) & .244 & NON- SIGNIFICANT \\
\hline $\begin{array}{c}\text { Outlining and } \\
\text { Summarizing }\end{array}$ & .309 & Moderate $(+)$ & .011 & SLIGHTLY SIGNIFICANT \\
\hline $\begin{array}{c}\text { Comparing and } \\
\text { Contrasting }\end{array}$ & .315 & Moderate $(+)$ & $.035^{* *}$ & SLIGHTLY SIGNIFICANT \\
\hline Evaluating & $.515^{* *}$ & Strong (+) & $.0003^{* *}$ & .007 \\
\hline Combined Strategies & .396 & Moderate $(+)$ & SIGNIFICANT \\
\hline
\end{tabular}

** rounded off to the nearest thousandths

Among the critical reading strategies, evaluating obtained the highest coefficient value $(0.515)$ which shows that there is a strong positive correlation between evaluating as a critical reading strategy and reading comprehension. 
This means that students comprehend the text more when they are able to evaluate the text considering the arguments and pieces of evidence presented by the writer.

Another strategy that significantly correlates with reading comprehension is contextualizing, $(r=0.422)$. The other strategies are only slightly significant in terms of how the respondents performed in the reading comprehension test. This result indicates that when learners are able to understand the text's context or background, they comprehend the text quite easily.

Correlation between critical reading strategies and analytical writing:

Table 4 shows the correlation between critical reading strategies and analytical writing performance of the respondents. The results show that critical reading strategies show moderate positive correlation to analytical writing. However, of the seven indicators, comparing and contrasting posted the highest correlation value (moderate) of 0.404 and a significance $\mathrm{F}$ of 0.006 . Three of the critical reading strategies namely: contextualizing, reflecting, and outlining and summarizing strategies yielded a "slightly significant"correlation.

Table 4:- Correlation between critical reading strategies and analytical writing performance of the respondents.

\begin{tabular}{|c|c|c|c|c|}
\hline STRATEGY & PEARSON'S $\boldsymbol{R}$ & INTERPRETATION & $\begin{array}{c}\text { SIGNIFICANCE } \\
\text { F }\end{array}$ & INTERPRETATION \\
\hline Previewing & $.181^{* *}$ & Weak $(+)$ & $.235^{* *}$ & NON-SIGNIFICANT \\
\hline Contextualizing & .308 & Moderate (+) & .039 & $\begin{array}{c}\text { SLIGHTLY } \\
\text { SIGNIFICANT }\end{array}$ \\
\hline Questioning & $.214 * *$ & Weak $(+)$ & .158 & NON-SIGNIFICANT \\
\hline Reflecting & .396 & Moderate $(+)$ & .007 & SLIGHTLY \\
\hline $\begin{array}{c}\text { Outlining and } \\
\text { Summarizing }\end{array}$ & .349 & Moderate $(+)$ & $.019 * *$ & SLIGHTLY \\
\hline $\begin{array}{c}\text { Comparing and } \\
\text { Contrasting }\end{array}$ & $.404 * *$ & Moderate $(+)$ & $.006 * *$ & SIGNIFICANT \\
\hline Evaluating & $.214 * *$ & Weak $(+)$ & .158 & NON-SIGNIFICANT \\
\hline $\begin{array}{c}\text { Combined } \\
\text { strategies }\end{array}$ & $.385^{* *}$ & Moderate $(+)$ & & SLIGHTLY \\
\hline
\end{tabular}

** rounded off to the nearest thousandths

Questioning and evaluating are also positively correlated to reading comprehension; however, the coefficient value is only 0.214 which shows weak correlation based on the guide provided by Evans (1996).

It is evident from these data that students used different critical reading strategies while answering reading comprehension test and writing analytical essay. In reading comprehension test, both evaluating and contextualizing as a critical reading strategy served as a significant strategy to utilize, while in analytical writing, comparing is the only strategy that shows high level of significance. However, reflecting and outlining served as slightly significant in both reading comprehension and in analytical writing, and these are the only strategies which posted relevance in both areas.

Perhaps, the reason behind this phenomenon is that the value of reflection in learning lies in the ability of the learners to clarify their thoughts, to gain insights and to deepen their understanding of the information that they received.Reflection is a deliberate cognitive activity where learners connect thoughts, feelings, and experiences related to the learning activity in which they are involved in. It allows learners to internalize and interlace the information gathered by reading and concretize these abstract ideas by writing. And when we both read and write, we need to clarify and comprehend the information which we read and/or write by making connection with our own ideas and insights that we have gained previously from our own experiences.

Aside from reflecting, outlining and summarizing also help organize our thoughts, the information obtained from reading, and the ideas that are about to be written. A descriptive outline leads to discover the main ideas together with the details, facts, explanations, and other additional supporting ideas. Thus, figuring out the main idea, details, facts, and explanation while reading and before writing are the fundamental steps that both readers and writers must undergo in order to comprehend the text fully and to create an organized writing. 


\section{Correlation between reading comprehension and writing performance:-}

Results in Table 5 show positive correlation $(r=0.19)$ between reading comprehension and analytical writing performanceof the respondents. Though the relationship is weak, correlation still exists. Had the respondents been increased in size, correlation value would more likely increase as well. Hence, increase in the size of respondents is recommended to make the results conclusive.

Table 5:Correlation between reading comprehension and the analytical writing performance of the respondents.

\begin{tabular}{|c|c|c|c|}
\hline PEARSON'S $\boldsymbol{R}$ & INTERPRETATION & SIGNIFICANCE F & INTERPRETATION \\
\hline 0.349 & Moderate $(+)$ & $0.019^{* *}$ & SLIGHTLY SIGNIFICANT \\
\hline
\end{tabular}

** rounded off to the nearest thousandths

$91 \%$ of the respondents scored average, 27 points out of 35 items, in the reading comprehension test and the weighted mean of the strategies used by these respondents is 3 out of 5. This data reveal that students who used strategies at average frequency also gained average scores in reading comprehension.

The findings of the study are not conclusive because there are also other variables that might have come into play during the administration of the study. In the tests administered, the researchers were not able to note which strategies the respondents used or whether the respondents used other strategies not mentioned in the study as they answered the tests.The researchers were also not able to take into account the other factors that might have affected the results of the tests such as internal or external problems experienced by the participants and the affective and cognitive factors such as attitudes, reading and writing skills(Unal\&Iseri, 2012).

\section{Discussion:-}

Four major findings emerged in this study and these are discussed in each subheadingbelow.

\section{Critical Reading Strategies Employed by the College Education Students:-}

Reflecting on challenges to the beliefs and values of the readers served as the most frequently used by the respondents of the study because in this strategy, the readers mark the concepts that challenged their beliefs and values (Salisbury University 2009) which creates a personal connection between the text and the reader by examining his personal responses (Salisbury University 2009) that will both help him understand the text and himself as a reader. Moreover,this strategy requires highlighting which serves as a good and easy way to understand and recall a concept from a certain text. Students are said to most likely answer a question correctly if they had highlighted the important word or phrase than if they did not (Peterson, 1992).

Contextualizing, the second most frequently used critical reading strategy,allows the readerto read the text with the lens of his own experience (Salisbury University 2009). But according to Salisbury University (2009), a reader must consider the difference of the past to current time. In that way, it is believed that the reader understands the text better by reading, keeping in mind the values and beliefs of the time when the text was written and the culture of the people in which the author is in. Although this strategy serves as a good way to comprehend a text, it only served as second as the most frequently used critical reading strategy for the reason that it is not as feasible as reflecting on beliefs and values because contextualizing is not always applicable since there are texts wherein knowing the authors' backgroundsand the texts' context does not affect the reader's understanding of the text (Rodriguez, 2003). Moreover, contextualizing requires the reader to place the text in its historical, biographical, and cultural context and readers may not have ample information to perform contextualization while reading.

\section{Critical Reading Strategies and Reading Comprehension:-}

There is a moderate positive correlation between critical reading strategies and reading comprehension $(r=0.396)$. It means that the more frequent learners use critical reading strategies, the more improved their comprehension would be. This finding corroborates the results of other researches in the field (Muhandiki, 1984; Duke \& Pearson (2002); Khabiri\&Pakzad, 2011;Sandy Ming -San Chang, 2013; Kadir et al., 2014). Thus, language teachers should provide direct instruction on critical reading strategies and design learning tasks for students to apply critical reading strategies.

Contextualization, which gained the second most significant correlation with comprehension, allows the reader to understand the text better by placing it in its historical, biographical, and cultural contexts (Salisbury University, 2009). Moreover, it is an approach in which skills are taught with direct reference to real-life situations in order to 
make the skills meaningful to students (Johnson, 2002), instead of teaching reading and writing skills in abstract way, it has to be taught meaningfully (contextualized literacy instruction) focusing on authentic content(Perin\& Hare, 2010). When a student is able to contextualize a text, he/she has the better grasp of the text; he can scrutinize it better and becomes information literate who can "evaluate information critically and competently" (AASL and AECT 1998:14).

The combined strategies posed moderate correlation (0.396) with reading comprehension almost similar when they are used individually. The study yielded almost similar results to the four strategies: contextualizing, reflecting on the challenges to beliefs and values, outlining and summarizing, comparing and contrasting which signifies that the combined strategies do not make any difference when applied to reading. Hence, it can be surmised that one strategy could be enough to attain the same level of performance of combined strategy as long as that particular strategy is optimally used.

\section{Critical Reading Strategies and Analytical Writing:-}

A moderate positive correlation exists between critical reading strategies and analytical writing. This indicates that as learners frequently use critical reading strategies, they perform better in analytical writing. Among the critical reading strategies that posted moderate positive correlation with analytical writing include comparing and contrasting ( $r=0.404)$, reflecting ( $r=0.396)$, outlining and summarizing $(r=0.349)$, and contextualizing $(r=.0308)$. All these strategies are relevant in analytical writing in the sense that before one can critically analyze a text, he/she needs to compare it with other texts in terms of content including arguments and pieces of evidence; he/she also must reflect on whether or not it challenges his/her beliefs and values; he/she should consider the text organization considering its outline and main points presented; and finally, he/she needs to study the context or historical background of the text to formulate sound judgment on its content and logic.

As what the University of Leicester's (n.d.) states, "critical reading is an important precursor to critical writing" (para. 1). Knott (2002, para. 1) likewise posits that, "critical writing depends on critical reading." Since results of the study show that these three essential techniques present substantial correlation to both enhanced reading comprehension and improved analytic writing performance, namely: 1) evaluation of the text read; 2) contextualizing the information from the text; and 3) reflecting on the reader's values and beliefs in relation to the texts read, focus can be made in teaching these three critical reading strategies to students to make them not only critical readers, but also critical thinkers and writers.

\section{Writing Performance and Reading Comprehension:-}

Results of the study show that there is a positive moderate correlation between analytical writing performance and reading comprehension. Likewise, it supports previous studies that reading andwriting are two aspects that are interrelated. In the study of Al-Saadat(2004), it shows that even though reading and writing are not what is defined as reciprocals, reading and writing have important relationship with each other "They share many cognitive skills and are viewed as mutually reinforcing interactive processes" (p.226). Moreover, Fountas and Pinnell (1996) stress that reading and writing are interrelated implying that the skills learned in one influences and reinforces the other. Hence, educators should strive to develop these two macro skills among learners across age groups.

\section{Conclusion:-}

This study reveals that the critical reading strategies somehow influence students' reading and writing performance. Hence, learners may try to learn and to adapt these strategies. As proven by studies cited in this research, critical reading strategies affect positively reading comprehension and writing performance.

The study also sought to identify the extent to which critical reading strategies were used, on how these strategies were utilized or whether the participants were able to maximize the use of these strategies. While the findings of the study show reflecting and contextualizing as the frequently used critical reading strategies by college education students, it is best to remember that amidst the numerous strategies available, there is no single best strategy that would fit all individuals and texts. Hence, educators may introduce several critical reading strategies in their classroom instruction to make their students become critical thinkers and analytical writers.

Another major finding of this study is that there is a moderate correlation between reading comprehension and critical reading strategies. Despite its moderate correlation value, we cannot deny that reading should be done in a systematic way where readers know how to gain the information and know whether to accept or not to accept the 
information gained. It is highly suggested that teachers cultivate the students' habit of using critical reading strategies so that they will become active processors of knowledge where meaning-making is facilitated. This intellectual exercise will eventually make these learners proficient critical readers who will not just accept things that they read but rather evaluate the veracity of information and the logic of ideas presented in the text.

For further research undertakings, a follow up study can be conducted to find out whether correlations among the variables under study exist among respondents acrossability levels (e.g. proficient, average and poor readers). The study may also investigate on the frequently used critical reading strategies employed by different types of readers. Furthermore, a study on what critical reading strategies can be used in reading and writing different types of genrescan also be conducted.Thus, this study may serve as a springboard for more research in the development of critical reading strategies in relation with reading comprehension and writing performance.

\section{References:-}

1. AbdKadir, N. (2014). The importance of teaching critical reading skills in a Malaysian reading classroom. The importance of teaching critical reading skills in a Malaysian reading classroom, 208-218.

2. Akın, F., Koray, O. \&Tavukçu, K. (2015). How effective is critical reading in the understanding of scientific.Procedia - Social and Behavioral Sciences, 174(12), 2444-2451. doi:2444 - 2451.

3. Ali Nasrollahi, M., Krishnasamy, P.N. \& Noor, N. M. (2015). Process of implementing critical reading strategies in an Iranian EFL classroom: an action research.

International Education Studies, 8(1), 9-15. doi:1913-9039

4. Allen, J. (2004). Tools for teaching content literacy. Portland, ME: Stenhouse.

5. Andrusyszyn, M.A. \& Davie, L. (1997). Facilitating reflection through interactive journal writing in an online graduate course: a qualitative study. Journal of Distance Education. Al-Saadat, A. (2004). Investigating the relationship of reading and writing abilities in the English Language Program at King Faisal University. Scientific Journal of King Faisal University (Humanities and Management Sciences), 5(1), 215-229.

6. Anderson-Medius, L. (1990). Cognitive mapping as a "bridge" activity. Paper at the Annual Meeting of the International Reading Association (35th, Atlanta, GA, May 6-11, 1990) (ERIC Document Reproduction Service No. ED. 320 140).

7. Axelrod, R. \&Cooper, C. (1999). A catalog of critical reading strategies. reading critically, writing well: A reader and guide $\left(5^{\text {th }}\right.$ ed)., New York: Bedford/St. Martin's, 1999.

8. Bengü, A. (2015). From descriptive to critical writing: A study on the effectiveness of advanced reading and writing instruction. GlobELT: An International Conference on Teaching and Learning English as an Additional Language, 199, 620 - 626-620 - 626. doi:1877-0428

9. Bianco, L., \&McCormick, S.(1989). Analysis of effects of a reading skill program for high school learning disabled students. Journal of Educational Research, 82, 282-288.

10. Bisset, J. (2014, February). Critical evaluation: Critical reading \& critical thinking. Research Department. Durnham University. Retrieved from: http://www.slideshare.net/bissetjm/criticalevaluation-critical-reading-critical-hinking

11. Bissett, D. (1970). The usefulness of children's books in the reading program. In J. Catterson (Ed.), Children and literature (pp. 73-80). Newark, DE: International Reading Association.

12. Bos, C. S.\& Anders, P.L. (1990). Effects of interactive vocabulary instruction on the vocabulary learning and reading comprehension of Junior high learning disabled students.Learning Disability Quarterly, 13(1), 31-42.

13. Buehl, D. (2007). A professional development framework for embedding comprehension instruction into content classrooms. In J. Lewis \& G. Moorman (Eds.), Adolescent literacy instruction: Policies and promising practices (p. 200). Newark, DE: International Reading Association.

14. Cimmiyotti, C. (n.d.). Impact of reading ability on academic performance at the primary level. Master's Theses and Capstone Projects, (127).

15. Collins, A., Brown,J.S. \& Larkin, K.M. (1980). Inference in text understanding. In R. J.

Spiro, B. C. Bruce, \& W. F. Brewer (Eds.), Theoretical issues in reading comprehension (pp. 385-407). Hillsdale, NJ: Erlbaum.

16. Connors-Tadros, L. (2014). National and state definitions of reading proficiency and measurement of reading proficiency (CEELOFASTfact). New Brunswick, NJ: Center on Enhancing Early Learning Outcomes

17. Conversational processes and causal explanation. Psychological Bulletin, 107, 65-81. 
18. Cook, J. (2006). The relationship between reading comprehension skill assessment methods and academic success for first semester students in a selected bachelor of science in nursing program in Texas. Retrieved from http://oaktrust.library.tamu.edu/bitstream/handle/1969.1/4728/etd-tamu-2006C-EHRD-Cook.pdf.

19. Corder-Ponce, W. L. (2000). Summarization interaction: Effects on foreign language comprehension and summarization of expository texts. Reading Research andInstruction, 39(4), 329-350.

20. Craig, S., Gholson, B., Ventura, M.,Graesser, A.\& Tutoring research group. (2000). Overhearing dialogues and monologues in virtual tutoring sessions: Effects on questioning and vicarious learning. International Journal of Artificial Intelligence in Education, 11, 242-253. Retrieved from http://iaied.org/pub/1031/file/1031_paper.pdf

21. Critical reading strategies. (2009). Retrieved November 26, 2015, from http://www.salisbury.edu

22. Crowell, D., \& Au, K. (1979). Using a scale of questions to improve listening comprehension. Language Arts, $56,38-43$.

23. Cui, Y., \& Zhao, Y. (2014). A contextual perspective on presupposition, with reference to translation studies. Stellenbosch Papers in Linguistics Plus,43, 31-42.doi:10.5842/43-0-180

24. Dansereau, D. G., McDonald, B.A., Long, G.L., Atkinson, T.R., Ellis, A.M., Collins, K.W.,Williams, S.\&Evans, S.H. (1974). The development and assessment of an effective learning strategy training program (Rep. No. 3). Fort Worth, TX: Texas Christian University

25. Doctorow, M., Wittrock, M. C.\&Marks, C. (1978). Generative processes in reading comprehension. Journal of Educational Psychology, 70, 109-118.

26. Dole, 1. A., Valencia, S.W.,Greer, E.A. \&Wardrop, J.L. (1991). Effects of two types of prereading instruction on the comprehension of narrative and expository text.Reading Research Quarterly, 26, 142-159.

27. Duke, N.\& Pearson, D. (2002). Effective practices for developing reading comprehension. In What research has to say about reading instruction (3rd ed., pp. 205-210). International Reading Association.

28. Duncan, J. (2014). Reading critically. The Writing Centre.

29. Duran, E. \&Yalçintaş, E. (2015) Review of the critical reading education in the primary schools.Science Direct, 174doi: $1560-1566$

30. Echevarria, J., Vogt, M.\&Short, D.J. (2008).Making content comprehensible for English learners. (3rd ed.). Boston, MA: Pearson Education.

31. Evans, J. D. (1996). Straightforward statistics for the behavioral sciences. Pacific Grove,CA:Brooks/Cole Publishing.

32. Fitzgerald, M.A. (1999). Evaluating information: An information literacy challenge. School Library Media Research, 2, 1523-4320.

33. Flemming, L. (2009). Reading for thinking (8th ed.). Stamford, CT: Cengage Learning.

34. Fountas, I. C.\&Pinnell, G.S. (1996). Guided reading: Good first teaching for all children.Portsmouth, NH: Heinemann.

35. Graesser, A.C. (Eds.). Questions and information systems Hillsdale, NJ: Erlbaum.Hilton, D. J. (1990).

36. Graesser, A. C., Person, N.K. \& Huber, J.D. (1992). Mechanisms that generate questions.In T. E. Lauer, E. Peacock, \& A. C.

37. Graves, M. F., Juel, C. \&Graves, B.B.(1998).Teaching reading in the 21st century., Allyn and Bacon, Des Moines, IA 50336-1071.

38. Guszak, F. (1967). Teacher questioning and reading. The Reading Teacher, 21, 227-234.

39. Halpern, D.F. (2003), Thought \& knowledge: An introduction to critical thinking. (4th ed.) Lawrence Erlbaum Associates, Mahwah, NJ.

40. Hansen, J. (1981). An inferential comprehension strategy for use with primary grade children. The Reading Teacher, 34, 665-669.

41. Harvard University.(2015, December).Interrogating texts. Retrieved from:http://guides.library.harvard.edu/sixreadinghabits

42. Higgs, J. (1988) Developing student autonomy in learning(2nd ed.). Boud, D. (Ed.). Abingdon, OX: Taylor \& Francis

43. Huck, C. S. (1976). Children's literature in the elementary school (3rd ed.). New York: Holt, Rinehart and Winston.

44. Huegl, V. (2008). Strategies for Reading. QLWG Skills for Life Series, 12, 3-14. Retrieved from http://www.nald.caHunter College Reading/Writing Center (n.d.). Invention: annotating a text. Retrieved from: http://rwc.hunter.cuny.edu/reading-writing/on-line/annotating-a-text.pdf

45. Imam, O. (2013). Correlation between reading comprehension skills and students' performance in mathematics. International Journal of Evaluation and Research in Education (IJERE),2(1), 1-8. doi:2252-8822 
46. Imam, O., Mastura, M.A, Jamil, H.\&Ismail, Z.(2014). Reading comprehension skills and performance in science among high school students in the Philippines. Asia PacificJournal of Educators and Education,29, 8194.

47. Ismail, J., Jamal, V.,Kadir, F.N.\&Subki, R. (2014). The importance of teaching critical reading skills in a Malaysian reading classroom. The 2014 WEI International Academic Conference Proceedings, Bali Indonesia.

48. Ivino, S.F. (1989). The effect of dominant hemispheric processing modes and notetaking strategy on the comprehension and retention of academically underprepared college readers. Paper presented at the annual meeting of the College Reading Association (33rd Philadelphia, PA, November 3-5, 1989) (ERIC Document Reproduction Service No. ED. 333 337).

49. Jasim, B. (2007). The impact of instruction in critical reading strategies on advanced Iraqi EFL learners' comprehension. College of Basic Education Researchers Journal, 7(1 ), 320-363.

50. Johnson, E. B. (2002). Contextual teaching and learning: What it is and why it's here tostay. Thousand Oaks, CA: Corwin Press.

51. Kadir, N. A., Roose,S.N., Ahmad, F.H. Jamal, A.\& Ismail, J. (2014). The importance ofteaching critical reading skills in a Malaysian reading classroom. Paper presented inInternational Academic Conference, May, Bali, Indonesia.

52. Karadă̆ R. (2014) Primary school teacher candidates' views towards critical reading skills and perceptions of their competence Science Direct,152doi:889 - 896

53. Khabiri, M.\&Pakzad, M.(2012). The effect of teaching critical reading strategies on EFL learners' vocabulary retention.The Journal of Teaching Language Skills (JTLS),4(1).

54. Kintsch, W. (1998).Comprehension: A paradigm for cognition. Cambridge: Cambridge University Press

55. Knott, D. (2012). Critical reading. New College Writing Center. University of Toronto Press - Scarborough. Retrieved from: $\quad$ www.utsc.utoronto.ca/twc/sites/utsc.utoronto.ca.twc/.../CriticalReading.pdf

56. Krishnasamy, P., Nasrollahi, M. \& Noor, N. (2015). Process of Implementing Critical Reading Strategies in an Iranian EFL Classroom: An Action Research. International Education Studies, 8(1), 9-16.

57. Kurland, D. (1998). How the language really works: The fundamentals of critical reading and effective writing. Journal of Reading, College Composition and Communication. Wadsworth. Retrieved from: http://www.criticalreading.com/critical_reading_thinking.htm

58. Lamme, L. (1981). Learning to love literature: Preschool through grade 3. Urbana, IL: National Council of Teachers of English.

59. Lanier, R.\& Davis, A. (1972). Developing comprehension through teacher-made questions. The Reading Teacher, 26, 153-157.

60. Marshall, J. (2006). The effects of participation in literature circles on reading comprehension. Open Access Dissertations. doi:2006-06-06.

61. McCormick, S. (1989). Effects of previews on more skilled and less skilled readers' comprehension of expository text. Journal of Reading Behaviors, 21, 219-239.

62. Morrow, L. (1984). Reading Stories to young children: Effects of story structure and traditional questioning strategies on comprehension. Journal of Reading Behavior, 16, 273-288.

63. NasrollahiM.A.,Krishnasamy, P. N.\&Noor, N. M. (2015). Identifying the critical reading strategies employed by Iranian EFLlearners. International J. Soc. Sci. \& Education, 5(2),360-373.

64. National Writing Project \& Nagin, C. (2006) Because writing matters. San Francisco, California: Josse-Bass.

65. Ong, R. (n.d.). The role of reflection in student learning: a study of its effectiveness in complementing problembased learning environments. Centre for Educational Development. Retrieved from http://www.myrp.sg/ced/research/papers/role_of_reflection_in_student_learning.pdf

66. Owusu-Acheaw, M.\&Larson, A. (2014). Reading habits among students and its effect on academic performance: A study of students of Koforidua Polytechnic. Library Philosophy and Practice. doi:6-5-2014

67. Pang, J. (2008). Research on good and poor reader characteristics: Implications for L2 reading research in China. Reading in a Foreign Language, 20(1)-1-18. doi:1539-0578

68. Perin, D. \& Hare, R. (2010). A contextualized reading-writing intervention for community college students. Community College Research Center, 44, 1526-2049.

69. Peterson, S. E. (1992). The cognitive functions of underlining as a study technique. Reading Research and Instruction 31,2. 49-56.

70. Pretorius, E. (1995). The importance of reading. A guide to learning English. Retrieved from: http://esl.fis.edu/parents/advice/read.htm 
71. Rockowitz, A. (n.d.).The writing processinvention: Annotating a text. Writing Center, Hunter College. Retrieved fromhttp://www.hunter.cuny.edu/rwc/repository/files/the-writing-process/invention/annotating-atext.pdf

72. Rodriguez, G. (2003). Biographical accounts as a workable strategy in educational research. Retrieved from http://www.leeds.ac.uk/educol/documents/00003625.htm

73. Rublee, M. (2005.). Teaching analytical writing through rubrics. Retrieved October 10,2015 from http://uncw.edu/cas/documents/TeachingAnalyticalWritingthroughRubrics.pdf

74. Salisbury University (2009). 7 Critical Reading Strategies.

Retrieved from: http://www.salisbury.edu/counseling/new/7_critical_reading_strategies.html

75. Schwartz, E.\&Sheff, A. (1975). Student involvement in questioning for comprehension. The Reading Teacher, $29,150-154$.

76. Silver, H. (2010). Compare and contrast: Teaching comparative thinking to strengthen student learning. United States: Silver Strong \& Associates.

77. Slater, W., Graves, M.F.\&Piche,G.L. (1985). Effects of structural organizers on ninth grade students' comprehension and recall of four patterns of expository text. Reading Research Quarterly, 20, 189-202.

78. Snow, R. (2002). Reading Comprehension. National Center of Literacy and Numeracy for Adults. October 26, 2012. Retrieved from:http://www.literacyandnumeracyforadults.com/resources/354679

79. Sousa, D. A. (2011).How the brain learns (4th ed.). Thousand Oaks, CA: Corwin.

80. Swanson, H.L.\& Keogh, B. (Eds.), Learning disabilities: Theoretical and research issues, Lawrence Erlbaum Associates, Hillsdale, New Jersey (1990) pp. 247-261

81. Swender, E.,Conrad, D., Vicars, R. (2012).ACTFL proficiency guidelines (3rd ed., pp. 20-24). Alexandria: American Council on the Teaching of Foreign Languages.

82. Tompkins, G. (1999). A Framework for literacy: Balancing instruction in the elementary classroom. Standerford, N. (Ed.). Needham, MA: Pearson Custom Publishing.

83. Treptow, M.A. (2006). Reading at Students' Frustrational, instructional, and independent levels: Effects on comprehension and time on-task. Minneapolis, MN: University of Minnesota Center for Reading Research.

84. Unal, E. \&Iseri, K. (2012). Analysis of the relationship between reading and writing attitudes of teacher candidates and their academic achievements through the structural equation model. Elementary Education Online, 11(4), 1066-1076.

85. University of Leicester. (n.d). What is Reading. Retrieved from: http://www2.le.ac.uk/offices/ld/resources/writing/writing-resources/critical-reading.

86. What is critical reading? (2009).Student learning development. Retrieved from https://www2.le.ac.ukz

87. Wolf, W., Huck, C.\& King, M. (1967). Critical reading ability of elementary school children.U.S. Department of Health, Education and Welfare, Project No. 4.

88. Yau, J. C. (2005). Two Mandarin readers in Taiwan: Characteristics of children with higher and lower reading proficiency levels. Journal of Research in Reading, 28(2), 108-123.

89. Yu, J. (2015). Analysis of critical reading strategies and its effect on college English reading. Theory and Practice in Language Studies,5(1),134-138. 